\title{
Triterpenoid Saponins from Anemone rivularis var. Flore-Minore and Their Anti-Proliferative Activity on HSC-T6 Cells
}

\author{
Xiao-Yang Wang ${ }^{1,+}{ }^{\text {, Hui Gao }}{ }^{2,+}{ }^{,}$Xiao-Jie Xie ${ }^{1}$, Jirimubatu Jurhiin ${ }^{3}$, Mu-Zi-He Zhang ${ }^{1}$, \\ Yan-Ping Zhou ${ }^{1}$, Rui Liu ${ }^{1}$, Meng Ning ${ }^{1}$, Jin Han ${ }^{1, *}$ and Hai-Feng Tang ${ }^{4, *}$ \\ 1 Department of Pharmacy, People's Liberation Army Institute of Chinese Medicine, Beijing 100039, China; \\ steveplum@sina.com (X.-Y.W.); xiexiaojie1991@163.com (X.-J.X.); zhangmuzihe@163.com (M.-Z.-H.Z.); \\ zhouyp0102@126.com (Y.-P.Z.); liurui198003@yeah.net (R.L.); lemon1572@163.com (M.N.) \\ 2 People's Liberation Army Institute of Organ Transplantation, Beijing 100091, China; gaohui309@163.com \\ 3 Academy of Mongolian Medicine, Inner Mongolia Medical University, Hohhot 010110, China; \\ jormbut@163.com \\ 4 Institute of Materia Medica, School of Pharmacy, The Fourth Military Medical University, \\ Xi'an 710032, China \\ * Correspondence: hanjin302pharm@126.com (J.H.); tanghf71@fmmu.edu.cn (H.-F.T.); \\ Tel.: +86-10-6693-3225 (J.H.); +86-29-8477-4748 (H.-F.T.) \\ + The authors contribute equally to this work.
}

Received: 6 February 2018; Accepted: 21 February 2018; Published: 23 February 2018

\begin{abstract}
Five previously undescribed triterpenoid saponins (1-5), along with eight known ones (6-13), were isolated from the whole plants of Anemone rivularis var. flore-minore. Their structures were clarified by extensive spectroscopic data and chemical evidence. For the first time, the lupane-type saponins (3 and 12) were reported from the Anemone genus. The anti-proliferative activity of all isolated saponins was evaluated on hepatic stellate cells (HSC-T6). Saponins 12 and 13, which possess more monosaccharides than the others, displayed potent anti-proliferative activity, with $\mathrm{IC}_{50}$ values of 18.21 and $15.56 \mu \mathrm{M}$, respectively.
\end{abstract}

Keywords: Triterpenoid saponins; Anemone rivularis var. flore-minore; Anti-proliferative activity; HSC-T6

\section{Introduction}

The genus Anemone belongs to the family Ranunculaceae, which consists of about 150 species with a near global distribution. Triterpenoid saponins have been proved to be the main bioactive substances of this genus, which possess potentially useful bioactivities. These bioactivities include antitumor, antibacterial, insect deterrence, and anti-peroxidation, among others [1-8]. For a long time, several species of this genus, such as A. flaccida, A. raddeana, A. tomentosa, A. anhuiensis, A. altaica, have been used as Chinese traditional medicines. Anemone rivularis var. flore-minore is widely distributed in western China. The whole plants of $A$. rivularis var. flore-minore, named "Poniuqi", have been used as a folk medicine in Shaanxi Province for the treatment of hepatitis, stranguria, edema, emissions, etc. [9]. As part of our continuing study to explore bioactive natural products from the genus Anemone [10-17], we continued the investigation of this plant. In our present study, five new triterpenoid saponins (1-5), together with eight known ones (6-13) (Figure 1) were isolated, among which lupane-type saponins (3 and 12) were first reported from the Anemone genus. Herein, we describe the isolation and structural identification of these saponins, as well as their anti-proliferative activity on HSC-T6 cells. 


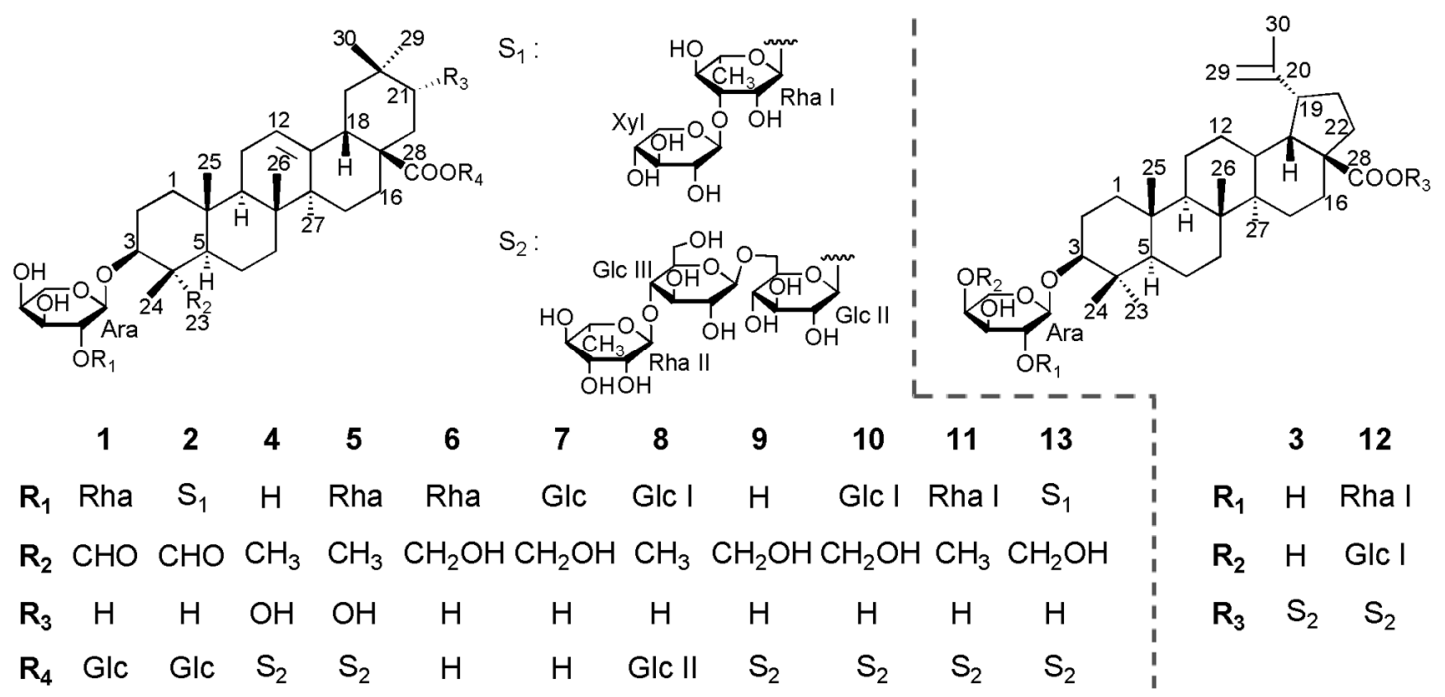

Figure 1. Structures of saponins 1-13.

\section{Results and Discussion}

Saponin 1 was obtained as a white amorphous powder and showed positive results in the Liebermann-Burchard and Molisch tests. Its molecular formula was established as $\mathrm{C}_{47} \mathrm{H}_{74} \mathrm{O}_{17}(\mathrm{~m} / z$ $933.4829[\mathrm{M}+\mathrm{Na}]^{+}$, calcd. for $\mathrm{C}_{47} \mathrm{H}_{74} \mathrm{O}_{17} \mathrm{Na}^{+}$, 933.4825) by high resolution electrospray ionization mass spectrometry (HRESIMS). The ${ }^{1} \mathrm{H}$ and ${ }^{13} \mathrm{C}$ NMR spectra exhibited signals for six tertiary methyl groups at $\delta_{\mathrm{H}} 0.86\left(\mathrm{H}_{3}-29\right), 0.87\left(\mathrm{H}_{3}-30\right), 0.89\left(\mathrm{H}_{3}-25\right), 1.05\left(\mathrm{H}_{3}-25\right), 1.19\left(\mathrm{H}_{3}-27\right)$, and $1.34\left(\mathrm{H}_{3}-24\right)$, one olefinic proton signal at $\delta_{\mathrm{H}} 5.41\left(1 \mathrm{H}, \mathrm{br}\right.$ s) with two typical olefinic carbon signals at $\delta_{\mathrm{C}} 122.7$ and 144.1, one carbonyl signal at $\delta_{\mathrm{C}} 176.6$, and one aldehyde proton signal at $\delta_{\mathrm{H}} 9.65(1 \mathrm{H}, \mathrm{s})$, with the corresponding aldehyde carbon signal at $\delta_{C} 206.5$. These data indicated that 1 was an oleanane-type saponin with one of the aglycone methyl groups substituted by an aldehyde function. The aldehyde function located at C-23 was deduced from the highfield shifts $(-6.7 \mathrm{ppm},-8.2 \mathrm{ppm}$, and $-6.9 \mathrm{ppm})$ exhibited by C-3 $\left(\delta_{C} 81.9\right), C-5\left(\delta_{C} 47.8\right)$, and C-24 $\left(\delta_{C} 10.3\right)$, respectively, and the downfield shift (+15.9 ppm) exhibited by $C-4\left(\delta_{C} 55.4\right)$ in comparison with the same carbon resonances in an oleanane skeleton bearing a Me-23 [15]. The $\alpha$-configuration for the 23-CHO function was determined by the correlations of $\mathrm{H}-23$ $\left(\delta_{\mathrm{H}} 9.65\right)$ with $\mathrm{H}-3\left(\delta_{\mathrm{H}} 4.04\right)$ and $\mathrm{H}-5\left(\delta_{\mathrm{H}} 1.36\right)$ observed in the NOESY spectrum (Figure 2$)$. The HMBC spectrum confirmed the 23-CHO function position by showing the correlations between $\mathrm{H}-23\left(\delta_{\mathrm{H}} 9.65\right)$ and C-3 $\left(\delta_{C} 81.9\right), C-4\left(\delta_{C} 55.4\right)$ and C-24 $\left(\delta_{C} 10.3\right)$ (Figure 2$)$. The assignments of the NMR signals of the aglycone moiety were derived from ${ }^{1} \mathrm{H}-{ }^{1} \mathrm{H}$ COSY, TOCSY, HSQC, HMBC, and NOESY spectra (Table 1). The aglycone of $\mathbf{1}$ was thus elucidated as gypsogenin [17-19]. The ${ }^{13} \mathrm{C}-\mathrm{NMR}$ shifts of C-3 at $\delta_{C} 81.9$ and $C-28$ at $\delta_{C} 176.6$ implied that sugar linkages were at both $C-3$ and $C-28$. The $\beta$-configuration for the 3-O-sugar moiety was deduced from the correlations of $\mathrm{H}-3$ with $\mathrm{H}-23$ and $\mathrm{H}-5$ observed in the NOESY spectrum (Figure 2).

The monosaccharides of $\mathbf{1}$ were determined as L-arabinose (Ara), L-rhamnose (Rha), and D-glucose (Glc), in a ratio of 1:1:1 by acidic hydrolysis followed by gas chromatography (GC) analysis [20]. The ${ }^{1} \mathrm{H}-\mathrm{NMR}$ spectrum of compound 1 exhibited three anomeric protons at $\delta_{\mathrm{H}}=6.32$ $(\mathrm{d}, J=8.2 \mathrm{~Hz}), 6.17(\mathrm{~s})$ and $5.03(\mathrm{~d}, J=7.3 \mathrm{~Hz})$, and one methyl group of 6-deoxy-hexopyranosyl moiety at $\delta_{\mathrm{H}} 1.62(\mathrm{~d}, J=6.2 \mathrm{~Hz})$. The $\alpha$ anomeric configuration of the Ara unit was deduced from the ${ }^{3} J_{\mathrm{H}-1 / \mathrm{H}-2}(7.3 \mathrm{~Hz})$ value observed in the ${ }^{4} C_{1}$ form. The Glc unit was determined to have a $\beta$ anomeric configuration on the basis of its ${ }^{3} \mathrm{~J}_{\mathrm{H}-1 / \mathrm{H}-2}$ coupling constant $(8.2 \mathrm{~Hz})$. Although the anomeric proton of the Rha moiety was observed as a singlet in the ${ }^{1} \mathrm{H}-\mathrm{NMR}$ spectrum, the ${ }^{13} \mathrm{C}-\mathrm{NMR}$ shift of Rha C-5 at $\delta_{C}=69.6$ indicated the $\alpha$ anomeric configuration [21,22]. The complete assignments of proton signals belonging to sugars were based on 2D NMR of ${ }^{1} \mathrm{H}-{ }^{1} \mathrm{H}$ COSY, TOCSY, and NOESY, and the carbon signals were assigned by HSQC and further confirmed by the HMBC spectrum (Table 2). The above 
NMR data indicated that all the monosaccharides were in their pyranose forms. The sequence and binding sites of the oligosaccharide chains were deduced from the HMBC spectrum (Figure 2). A cross peak between $\mathrm{C}-3$ of the aglycone and $\mathrm{H}-1$ of Ara revealed that Ara was connected to C-3 of the aglycone. Similarly, the linkage of Glc at C-28 of the aglycone was indicated by the cross peak Glc H-1/C-28, and the linkage of Rha at C-2 of Ara was indicated by the cross peak Rha H-1/Ara C-2. This conclusion was also supported by the NOESY correlations (Figure 2). On the basis of the above analysis, the structure of 1 was elucidated as $3 \beta-O-\alpha$-L-rhamnopyranosyl-( $1 \rightarrow 2)$ - $\alpha$-L-arabinopyranosyl gypsogenin 28-O- $\beta$-D-glucopyranosyl ester.

Table 1. ${ }^{1} \mathrm{H}-(500 \mathrm{MHz})$ and ${ }^{13} \mathrm{C}-\mathrm{NMR}(125 \mathrm{MHz})$ data for the aglycone moieties of $\mathbf{1}-\mathbf{5}$ in pyridine- $d_{5}$.

\begin{tabular}{|c|c|c|c|c|c|c|c|c|c|c|}
\hline \multirow{2}{*}{$\mathrm{C}$} & \multicolumn{2}{|r|}{1} & \multicolumn{2}{|r|}{2} & \multicolumn{2}{|r|}{3} & \multicolumn{2}{|r|}{4} & \multicolumn{2}{|r|}{5} \\
\hline & $\delta_{C}$ & $\delta_{\mathbf{H}}$ & $\delta_{C}$ & $\delta_{\mathbf{H}}$ & $\delta_{C}$ & $\delta_{H}$ & $\delta_{C}$ & $\delta_{H}$ & $\delta_{C}$ & $\delta_{\mathbf{H}}$ \\
\hline 1 & 38.5 & $0.97,1.55 \mathrm{~m}$ & 38.6 & $1.00,1.59 \mathrm{~m}$ & 39.4 & $1.60,0.89 \mathrm{~m}$ & 38.8 & $0.93,1.45 \mathrm{~m}$ & 38.9 & $0.95,1.46 \mathrm{~m}$ \\
\hline 2 & 25.7 & $1.84,2.09 \mathrm{~m}$ & 25.6 & $1.87,2.10 \mathrm{~m}$ & 26.8 & $2.18,1.86 \mathrm{~m}$ & 26.6 & $1.84,2.06 \mathrm{~m}$ & 26.7 & $1.87,2.08 \mathrm{~m}$ \\
\hline 3 & 81.9 & $4.04 \mathrm{~m}$ & 81.8 & $4.06 \mathrm{~m}$ & 88.7 & $3.34 \mathrm{~m}$ & 88.7 & $\begin{array}{c}3.26 \mathrm{dd} \\
(3.7,11.6)\end{array}$ & 88.8 & $\begin{array}{c}3.28 \mathrm{dd} \\
(3.9,11.6)\end{array}$ \\
\hline 4 & 55.4 & - & 55.6 & - & 39.6 & - & 39.4 & - & 39.5 & - \\
\hline 5 & 47.8 & $1.36 \mathrm{~m}$ & 48.0 & $1.37 \mathrm{~m}$ & 56.0 & $0.74 \mathrm{~m}$ & 56.0 & $0.77 \mathrm{~d}(11.5)$ & 56.1 & $0.79 \mathrm{~d}(11.6)$ \\
\hline 6 & 20.6 & $0.98,1.39 \mathrm{~m}$ & 20.7 & $0.99,1.42 \mathrm{~m}$ & 18.4 & $1.67,1.45 \mathrm{~m}$ & 18.4 & $1.25,1.44 \mathrm{~m}$ & 18.5 & $1.26,1.46 \mathrm{~m}$ \\
\hline 7 & 32.6 & $1.17,1.42 \mathrm{~m}$ & 32.7 & $1.19,1.42 \mathrm{~m}$ & 34.5 & $1.30,1.28 \mathrm{~m}$ & 33.1 & $1.25,1.40 \mathrm{~m}$ & 33.2 & $1.25,1.42 \mathrm{~m}$ \\
\hline 8 & 40.0 & - & 40.2 & - & 41.1 & - & 39.7 & - & 39.9 & - \\
\hline 9 & 47.8 & $1.69 \mathrm{~m}$ & 48.1 & $1.70 \mathrm{~m}$ & 50.8 & $1.30 \mathrm{~m}$ & 48.1 & $1.66 \mathrm{~m}$ & 48.2 & $1.68 \mathrm{~m}$ \\
\hline 10 & 36.0 & - & 36.2 & - & 37.1 & - & 36.9 & - & 37.0 & - \\
\hline 11 & 23.2 & $1.90,1.99 \mathrm{~m}$ & 23.4 & $1.91,2.03 \mathrm{~m}$ & 21.1 & $1.31,1.13 \mathrm{~m}$ & 23.7 & $1.86,1.92 \mathrm{~m}$ & 23.8 & $1.87,1.94 \mathrm{~m}$ \\
\hline 12 & 122.7 & 5.41 br s & 122.6 & 5.42 br s & 26.0 & $1.84,1.13 \mathrm{~m}$ & 122.6 & 5.43 br s & 122.8 & 5.44 br s \\
\hline 13 & 144.1 & - & 144.2 & - & 38.3 & $2.64 \mathrm{~m}$ & 144.1 & - & 144.3 & - \\
\hline 14 & 41.6 & - & 41.8 & - & 42.7 & - & 42.2 & - & 42.4 & - \\
\hline 15 & 28.1 & $1.13,2.04 \mathrm{~m}$ & 28.3 & $1.15,2.06 \mathrm{~m}$ & 30.1 & $2.00,1.18 \mathrm{~m}$ & 28.5 & $1.15,2.30 \mathrm{~m}$ & 28.6 & $1.16,2.32 \mathrm{~m}$ \\
\hline 16 & 23.2 & $1.77,2.01 \mathrm{~m}$ & 23.3 & $1.78,2.05 \mathrm{~m}$ & 32.4 & $2.63,1.48 \mathrm{~m}$ & 27.0 & $2.35,3.08 \mathrm{~m}$ & 27.1 & $2.37,3.11 \mathrm{~m}$ \\
\hline 17 & 47.2 & - & 47.3 & - & 57.0 & - & 47.1 & - & 47.2 & - \\
\hline 18 & 41.5 & $\begin{array}{c}3.14 \mathrm{dd} \\
(3.3,13.4)\end{array}$ & 41.7 & $\begin{array}{c}3.15 \mathrm{dd} \\
(3.9,13.5)\end{array}$ & 49.8 & $1.71 \mathrm{~m}$ & 41.5 & $\begin{array}{c}3.36 \mathrm{dd} \\
(3.3,14.0)\end{array}$ & 41.7 & $\begin{array}{c}3.38 \mathrm{dd} \\
(3.4,13.9)\end{array}$ \\
\hline 19 & 46.1 & $1.23,1.74 \mathrm{~m}$ & 46.2 & $1.24,1.75 \mathrm{~m}$ & 47.4 & $3.36 \mathrm{~m}$ & 41.3 & $1.70,1.21 \mathrm{~m}$ & 41.5 & $1.73,1.22 \mathrm{~m}$ \\
\hline 20 & 30.6 & - & 30.7 & - & 150.8 & - & 35.6 & - & 35.7 & - \\
\hline 21 & 33.8 & $1.12,1.34 \mathrm{~m}$ & 34.0 & $1.13,1.36 \mathrm{~m}$ & 30.8 & $2.15,1.40 \mathrm{~m}$ & 73.2 & 3.66 br s & 73.4 & 3.67 br s \\
\hline 22 & 32.3 & $1.71,1.89 \mathrm{~m}$ & 32.4 & $1.73,1.91 \mathrm{~m}$ & 37.1 & $2.19,1.45 \mathrm{~m}$ & 39.5 & $2.25,2.27 \mathrm{~m}$ & 39.6 & $2.26,2.28 \mathrm{~m}$ \\
\hline 23 & 206.5 & $9.65 \mathrm{~s}$ & 206.6 & $9.66 \mathrm{~s}$ & 28.1 & $1.24 \mathrm{~s}$ & 28.1 & $1.29 \mathrm{~s}$ & 28.2 & $1.30 \mathrm{~s}$ \\
\hline 24 & 10.3 & $1.34 \mathrm{~s}$ & 10.5 & $1.35 \mathrm{~s}$ & 16.3 & $0.77 \mathrm{~s}$ & 17.2 & $1.15 \mathrm{~s}$ & 17.3 & $1.16 \mathrm{~s}$ \\
\hline 25 & 15.6 & $0.89 \mathrm{~s}$ & 15.7 & $0.89 \mathrm{~s}$ & 16.7 & $0.92 \mathrm{~s}$ & 15.5 & $0.87 \mathrm{~s}$ & 15.7 & $0.88 \mathrm{~s}$ \\
\hline 26 & 17.3 & $1.05 \mathrm{~s}$ & 17.5 & $1.06 \mathrm{~s}$ & 16.4 & $1.10 \mathrm{~s}$ & 17.4 & $1.08 \mathrm{~s}$ & 17.6 & $1.10 \mathrm{~s}$ \\
\hline 27 & 26.2 & $1.19 \mathrm{~s}$ & 26.3 & $1.22 \mathrm{~s}$ & 14.8 & $1.03 \mathrm{~s}$ & 25.5 & $1.31 \mathrm{~s}$ & 25.7 & $1.33 \mathrm{~s}$ \\
\hline 28 & 176.6 & - & 176.7 & - & 174.9 & - & 176.4 & - & 176.6 & - \\
\hline 29 & 33.0 & $0.86 \mathrm{~s}$ & 33.1 & $0.87 \mathrm{~s}$ & 110.1 & $4.85,4.70$ (br s) & 28.3 & $1.13 \mathrm{~s}$ & 28.5 & $1.14 \mathrm{~s}$ \\
\hline 30 & 23.7 & $0.87 \mathrm{~s}$ & 23.8 & $0.88 \mathrm{~s}$ & 19.4 & $1.70 \mathrm{~s}$ & 24.8 & $0.99 \mathrm{~s}$ & 25.1 & $1.01 \mathrm{~s}$ \\
\hline
\end{tabular}

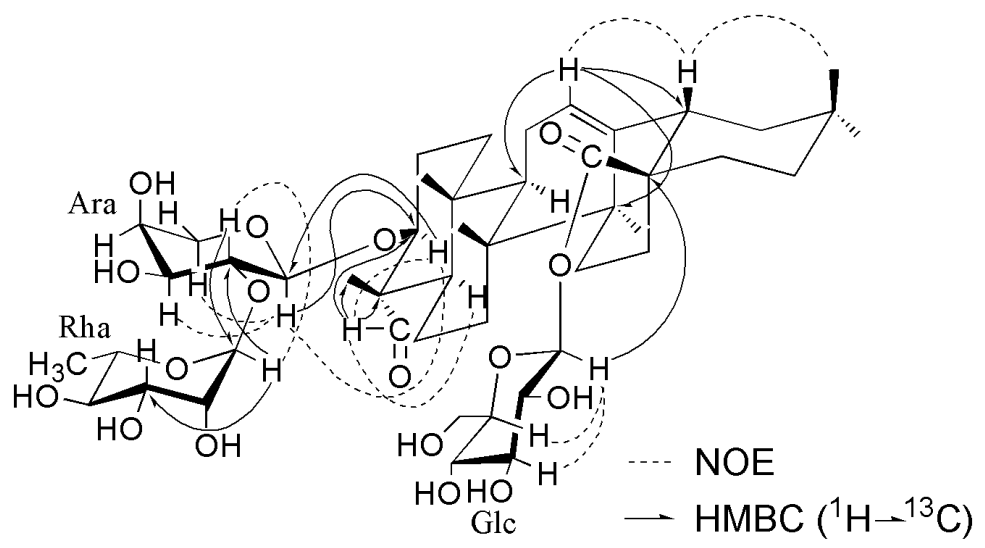

Figure 2. Key NOESY and HMBC correlations for compound 1. 
Table 2. ${ }^{1} \mathrm{H}-(500 \mathrm{MHz})$ and ${ }^{13} \mathrm{C}-\mathrm{NMR}(125 \mathrm{MHz})$ data for the sugar moieties of $\mathbf{1}-\mathbf{5}$ in pyridine- $d_{5}$.

\begin{tabular}{|c|c|c|c|c|c|c|c|c|c|c|}
\hline \multirow{2}{*}{ C } & \multicolumn{2}{|r|}{1} & \multicolumn{2}{|r|}{2} & \multicolumn{2}{|r|}{3} & \multicolumn{2}{|r|}{4} & \multicolumn{2}{|r|}{5} \\
\hline & $\delta_{C}$ & $\delta_{H}$ & $\delta_{C}$ & $\delta_{H}$ & $\delta_{C}$ & $\delta_{H}$ & $\delta_{C}$ & $\delta_{H}$ & $\delta_{C}$ & $\delta_{H}$ \\
\hline \multicolumn{11}{|c|}{ 3-O-sugar } \\
\hline \multicolumn{11}{|c|}{ Ara } \\
\hline 1 & 104.6 & $5.03 \mathrm{~d}(7.3)$ & 104.7 & $5.04 \mathrm{~d}(7.0)$ & 107.5 & $4.76 \mathrm{~d}(7.0)$ & 107.4 & $4.77 \mathrm{~d}(6.8)$ & 104.5 & $5.03 \mathrm{~d}(7.3)$ \\
\hline 2 & 75.7 & $4.43 \mathrm{~m}$ & 75.5 & $4.53 \mathrm{~m}$ & 72.9 & $4.40 \mathrm{~m}$ & 72.8 & $4.41 \mathrm{~m}$ & 75.5 & $4.43 \mathrm{~m}$ \\
\hline 3 & 74.7 & $4.16 \mathrm{~m}$ & 75.2 & $4.04 \mathrm{~m}$ & 74.6 & $4.13 \mathrm{~m}$ & 74.4 & $4.14 \mathrm{~m}$ & 74.6 & $4.16 \mathrm{~m}$ \\
\hline 4 & 69.3 & $4.20 \mathrm{~m}$ & 69.9 & $4.12 \mathrm{~m}$ & 69.5 & $4.29 \mathrm{~m}$ & 69.5 & $4.27 \mathrm{~m}$ & 69.3 & $4.20 \mathrm{~m}$ \\
\hline 5 & 65.7 & $3.75,4.42 \mathrm{~m}$ & 66.3 & $3.56,4.32 \mathrm{~m}$ & 67.1 & $3.80,4.28 \mathrm{~m}$ & 67.0 & $3.81,4.26 \mathrm{~m}$ & 65.5 & $3.76,4.42 \mathrm{~m}$ \\
\hline \multicolumn{11}{|c|}{ Rha I } \\
\hline 1 & 101.6 & $6.17 \mathrm{~s}$ & 101.3 & $6.32 \mathrm{~s}$ & & & & & 101.7 & $6.17 \mathrm{~s}$ \\
\hline 2 & 72.3 & $4.71 \mathrm{br} \mathrm{s}$ & 71.9 & 4.89 brs & & & & & 72.3 & 4.71 br s \\
\hline 3 & 72.5 & $4.59 \mathrm{~m}$ & 82.8 & $4.75 \mathrm{~m}$ & & & & & 72.4 & $4.59 \mathrm{~m}$ \\
\hline 4 & 74.1 & $4.28 \mathrm{~m}$ & 72.9 & $4.45 \mathrm{~m}$ & & & & & 74.0 & $4.27 \mathrm{~m}$ \\
\hline 5 & 69.6 & $4.61 \mathrm{~m}$ & 69.6 & $4.62 \mathrm{~m}$ & & & & & 69.8 & $4.61 \mathrm{~m}$ \\
\hline 6 & 18.5 & $1.62 \mathrm{~d}(6.2)$ & 18.4 & $1.52 \mathrm{~d}(6.2)$ & & & & & 18.6 & $1.62 \mathrm{~d}(6.2)$ \\
\hline \multicolumn{11}{|c|}{ Xyl } \\
\hline 1 & & & 107.5 & $5.35 \mathrm{~d}(7.7)$ & & & & & & \\
\hline 2 & & & 75.6 & $4.05 \mathrm{~m}$ & & & & & & \\
\hline 3 & & & 78.4 & $4.15 \mathrm{~m}$ & & & & & & \\
\hline 4 & & & 71.1 & $4.19 \mathrm{~m}$ & & & & & & \\
\hline 5 & & & 67.4 & $3.69,4.30 \mathrm{~m}$ & & & & & & \\
\hline \multicolumn{11}{|c|}{ 28-O-sugar } \\
\hline \multicolumn{11}{|c|}{ Glc I } \\
\hline 1 & 95.7 & $6.32 \mathrm{~d}(8.2)$ & 95.6 & $6.23 \mathrm{~d}(8.1)$ & 95.3 & $6.34 \mathrm{~d}(8.2)$ & 95.5 & $6.24 \mathrm{~d}(8.2)$ & 95.6 & $6.23 \mathrm{~d}(8.1)$ \\
\hline 2 & 74.1 & $4.19 \mathrm{~m}$ & 73.8 & $4.08 \mathrm{~m}$ & 74.0 & $4.08 \mathrm{~m}$ & 73.7 & $4.07 \mathrm{~m}$ & 73.8 & $4.10 \mathrm{~m}$ \\
\hline 3 & 79.2 & $4.02 \mathrm{~m}$ & 78.7 & $4.15 \mathrm{~m}$ & 78.7 & $4.20 \mathrm{~m}$ & 78.6 & $4.16 \mathrm{~m}$ & 78.7 & $4.17 \mathrm{~m}$ \\
\hline 4 & 71.1 & $4.34 \mathrm{~m}$ & 70.8 & $4.28 \mathrm{~m}$ & 70.9 & $4.29 \mathrm{~m}$ & 70.8 & $4.27 \mathrm{~m}$ & 70.7 & $4.30 \mathrm{~m}$ \\
\hline 5 & 78.9 & $4.26 \mathrm{~m}$ & 78.0 & $4.08 \mathrm{~m}$ & 78.0 & $4.08 \mathrm{~m}$ & 77.9 & $4.06 \mathrm{~m}$ & 78.0 & $4.09 \mathrm{~m}$ \\
\hline 6 & 62.3 & $4.40,4.43 \mathrm{~m}$ & 69.1 & $4.31,4.63 \mathrm{~m}$ & 69.4 & $4.30,4.66 \mathrm{~m}$ & 69.1 & $4.27,4.64 \mathrm{~m}$ & 69.0 & $4.30,4.63 \mathrm{~m}$ \\
\hline \multicolumn{11}{|c|}{ Glc II } \\
\hline 1 & & & 104.9 & $4.97 \mathrm{~d}(7.7)$ & 105.2 & $4.92 \mathrm{~d}(7.8)$ & 104.8 & $4.97 \mathrm{~d}(7.8)$ & 104.9 & $4.98 \mathrm{~d}(7.8)$ \\
\hline 2 & & & 75.3 & $3.92 \mathrm{~m}$ & 75.3 & $3.92 \mathrm{~m}$ & 75.2 & $3.91 \mathrm{~m}$ & 75.3 & $3.92 \mathrm{~m}$ \\
\hline 3 & & & 76.5 & $4.12 \mathrm{~m}$ & 76.4 & $4.11 \mathrm{~m}$ & 76.4 & $4.12 \mathrm{~m}$ & 76.5 & $4.14 \mathrm{~m}$ \\
\hline 4 & & & 78.1 & $4.40 \mathrm{~m}$ & 78.2 & $4.39 \mathrm{~m}$ & 78.1 & $4.37 \mathrm{~m}$ & 78.2 & $4.39 \mathrm{~m}$ \\
\hline 5 & & & 77.1 & $3.62 \mathrm{~m}$ & 77.2 & $3.63 \mathrm{~m}$ & 77.0 & $3.64 \mathrm{~m}$ & 77.1 & $3.64 \mathrm{~m}$ \\
\hline 6 & & & 61.2 & $4.07,4.18 \mathrm{~m}$ & 61.3 & $4.06,4.18 \mathrm{~m}$ & 61.2 & $4.04,4.19 \mathrm{~m}$ & 61.3 & $4.06,4.20 \mathrm{~m}$ \\
\hline \multicolumn{11}{|c|}{ Rha II } \\
\hline 1 & & & 102.6 & $5.85 \mathrm{~s}$ & 102.7 & $5.84 \mathrm{~s}$ & 102.6 & $5.84 \mathrm{~s}$ & 102.7 & $5.86 \mathrm{~s}$ \\
\hline 2 & & & 72.6 & $4.66 \mathrm{~m}$ & 72.6 & $4.65 \mathrm{~m}$ & 72.5 & $4.63 \mathrm{~m}$ & 72.6 & $4.64 \mathrm{~m}$ \\
\hline 3 & & & 72.7 & $4.53 \mathrm{~m}$ & 72.8 & $4.50 \mathrm{~m}$ & 72.7 & $4.50 \mathrm{~m}$ & 72.7 & $4.54 \mathrm{~m}$ \\
\hline 4 & & & 74.1 & $4.31 \mathrm{~m}$ & 74.0 & $4.30 \mathrm{~m}$ & 74.0 & $4.30 \mathrm{~m}$ & 74.1 & $4.32 \mathrm{~m}$ \\
\hline 5 & & & 70.3 & $4.94 \mathrm{~m}$ & 70.3 & $4.95 \mathrm{~m}$ & 70.3 & $4.92 \mathrm{~m}$ & 70.4 & $4.95 \mathrm{~m}$ \\
\hline 6 & & & 18.5 & $1.68 \mathrm{~d}(6.2)$ & 18.5 & $1.69 \mathrm{~m}$ & 18.5 & $1.67 \mathrm{~d}(6.2)$ & 18.6 & $1.66 \mathrm{~d}(6.2)$ \\
\hline
\end{tabular}

Saponin 2 was also obtained as a white powder. A pseudomolecular ion at $m / z 1065.5252$ (calcd. for $1065.5246[\mathrm{M}+\mathrm{Na}]^{+}$) was found in HRESIMS, establishing the molecular formula of $\mathrm{C}_{52} \mathrm{H}_{82} \mathrm{O}_{21}$. By comparing with the 1D NMR data of $\mathbf{1}$, the aglycone moiety of $\mathbf{2}$ was identical to $\mathbf{1}$ (Table 1), suggesting the same gypsogenin aglycone. The types of sugar units were determined as L-arabinose, D-xylose, L-rhamnose, and D-glucose in a 1:1:2:2 ratio by acid hydrolysis, followed by GC analysis. Six anomeric protons $\left(\delta_{\mathrm{H}} 6.32(\mathrm{~s}), 6.23(\mathrm{~d}, J=8.1 \mathrm{~Hz}), 5.85(\mathrm{~s}), 5.35(\mathrm{~d}, J=7.7 \mathrm{~Hz})\right.$, $5.04(\mathrm{~d}, J=7.0 \mathrm{~Hz})$, and $4.97(\mathrm{~d}, J=7.7 \mathrm{~Hz}))$ and six anomeric carbons $\left(\delta_{\mathrm{C}} 107.5,104.9,104.7,102.6\right.$, 101.3, and 95.6) were observed in the NMR spectra of 2. The linkage sites and the sequence of sugar moieties were deduced from the HMBC and NOESY correlations of signals at $\delta_{\mathrm{H}} 5.04(\mathrm{H}-1$ of Ara) with $\delta_{\mathrm{C}} 81.8$ (C-3 of the aglycone), $\delta_{\mathrm{H}} 6.32$ (H-1 of Rha I) with $\delta_{\mathrm{C}} 75.5$ (C-2 of Ara), $\delta_{\mathrm{H}}$ 
$5.35(\mathrm{H}-1$ of $\mathrm{Xyl})$ with $\delta_{\mathrm{C}} 82.8\left(\mathrm{C}-3\right.$ of Rha I), $\delta_{\mathrm{H}} 6.23\left(\mathrm{H}-1\right.$ of Glc I) with $\delta_{\mathrm{C}} 176.7$ (C-28 of the aglycone), $\delta_{\mathrm{H}} 4.97$ (H-1 of Glc II) with $\delta_{\mathrm{C}} 69.1$ (C-6 of Glc I), and $\delta_{\mathrm{H}} 5.85$ (H-1 of Rha II) with $\delta_{C} 78.1$ (C-4 of Glc II) (Figure S1 in Supplementary data). Thus, the structure of 2 was assigned as $3 \beta$-O- $\beta$-D-xylopyranosyl-( $1 \rightarrow 3)-\alpha$-L-rhamnopyranosyl-( $1 \rightarrow 2)-\alpha$-L-arabinopyranosyl gypsogenin 28-O- $\alpha$-L-rhamnopyranosyl-( $1 \rightarrow 4)-\beta$-D-glucopyranosyl-( $1 \rightarrow 6)-\beta$-D-glucopyranosyl ester.

Saponin 3 was obtained as a white powder. HRESIMS of 3 showed a quasi-molecular ion at $\mathrm{m} / z$ 1081.8564 (calcd. for $1081.8559[\mathrm{M}+\mathrm{Na}]^{+}$), establishing the molecular formula of $\mathrm{C}_{53} \mathrm{H}_{86} \mathrm{O}_{21}$. The $1 \mathrm{D}$ NMR data of 3 exhibited signals for six tertiary methyl groups at $0.77\left(\mathrm{H}_{3}-24\right), 0.92\left(\mathrm{H}_{3}-25\right), 1.03\left(\mathrm{H}_{3}-27\right)$, $1.10\left(\mathrm{H}_{3}-26\right), 1.24\left(\mathrm{H}_{3}-23\right)$, and $1.70\left(\mathrm{H}_{3}-30\right)$, an exomethylene group at $\delta_{\mathrm{H}} 4.70$ and 4.85 with two olefinic carbon signals at $\delta_{C} 110.1$ and 150.8 , and one carbonyl signal at $\delta_{C} 174.9$, which were characteristic of the $\Delta^{20(29)}$-lupane-type aglycone. The full assignments of the aglycone NMR signals were derived from 2D NMR data (Table 1), suggesting that the aglycone of 3 was betulinic acid $[23,24]$. The sugar moieties of 3 were determined as L-arabinose, L-rhamnose, and D-glucose in a ratio of 1:1:2 by acid hydrolysis, followed by GC analysis. Meanwhile, the 1D NMR spectra of 3 exhibited four anomeric protons at $\delta_{\mathrm{H}}$ $6.34(\mathrm{~d}, J=8.2 \mathrm{~Hz}), 5.84(\mathrm{~s}), 4.92(\mathrm{~d}, J=7.8 \mathrm{~Hz})$, and $4.76(\mathrm{~d}, J=7.0 \mathrm{~Hz})$, and four anomeric carbons at $\delta_{C} 107.5,105.2,102.7$, and 95.3 . The sequence and binding sites of the sugar units to each other and to the aglycone were deduced from the HMBC and NOESY spectra (Figure S2 in Supplementary data). On the basis of these findings, the structure of 3 was thus elucidated as $3 \beta-O-\alpha$-L-arabinopyranosyl betulinic acid 28 -O- $\alpha$-L-rhamnopyranosyl-( $1 \rightarrow 4)-\beta$-D-glucopyranosyl-( $1 \rightarrow 6)-\beta$-D-glucopyranosyl ester. The lupane-type saponin was reported from this genus for the first time.

Saponin 4 was obtained as a white amorphous powder. In the positive-ion mode HRESIMS, a pseudomolecular ion peak at $m / z 1097.5515[\mathrm{M}+\mathrm{Na}]^{+}$(calcd. for $\mathrm{C}_{53} \mathrm{H}_{86} \mathrm{O}_{22} \mathrm{Na}^{+}$, 1097.5508) was observed, suggesting a molecular formula $\mathrm{C}_{53} \mathrm{H}_{86} \mathrm{O}_{22}$. Seven tertiary methyl groups at $\delta_{\mathrm{H}} 0.87$ $\left(\mathrm{H}_{3}-25\right), 0.99\left(\mathrm{H}_{3}-30\right), 1.08\left(\mathrm{H}_{3}-26\right), 1.13\left(\mathrm{H}_{3}-29\right), 1.15\left(\mathrm{H}_{3}-24\right), 1.29\left(\mathrm{H}_{3}-23\right)$, and $1.31\left(\mathrm{H}_{3}-27\right)$, one olefinic proton at $\delta_{\mathrm{H}} 5.43(1 \mathrm{H}, \mathrm{br} \mathrm{s})$ with two typical olefinic carbon signals (at $\delta_{\mathrm{C}} 122.6$ and 144.1), and one carbonyl signal at $\delta_{C} 176.5$ were observed in the 1D NMR spectra of 4 . This revealed 4 as an oleanane-type saponin. Due to the change of chemical shift of C-21 from $\delta_{C} 31.4$ in oleanolic acid [25] to $\delta_{C} 73.2(+41.8)$ and the other of carbons such as C-18 $\left[\delta_{C} 41.5(-1.4)\right], C-19\left[\delta_{C} 41.3(-5.0)\right.$ ], C-20 $\left[\delta_{C} 35.6(+4.7)\right], C-22\left[\delta_{C} 39.5(+6.3)\right], C-29\left[\delta_{C} 28.3(-6.9)\right]$, and C-30 [ $\left.\delta_{C} 24.8(+0.1)\right], C-21$ must be an oxygen-bearing methylene carbon in the aglycone of 4 , which was confirmed by the HMBC experiment (Figure S3 in Supplementary data). The NOESY correlations between $\mathrm{H}-21\left(\delta_{\mathrm{H}} 3.66\right)$ and $\mathrm{H}_{3}-30$ $\left(\delta_{\mathrm{H}} 0.99\right)$ indicated the $\alpha$-orientation of $21-\mathrm{OH}$ (Figure S3 in Supplementary data). The assignments of the NMR signals associated with the aglycone moiety were derived from 2D NMR spectra (Table 1). These data revealed that the aglycone of 4 was $21 \alpha$-hydroxy-oleanolic acid, which was in a good agreement when comparing the literature data $[26,27]$. Further comparison of the 1D NMR data assignable to the sugar part between 4 and 3 led to the determination of the same monosaccharide units and glycosylation sequence observed for both at C-3 and C-28 (Table 2). The conclusion was confirmed by the HMBC and NOESY spectra data (Figure S3 in Supplementary data). Therefore, the structure of saponin 4 was elucidated as $3 \beta-O-\alpha$-L-arabinopyranosyl $21 \alpha$-hydroxy-oleanolic acid 28 -O- $\alpha$-L-rhamnopyranosyl-( $1 \rightarrow 4)-\beta$-D-glucopyranosyl-( $1 \rightarrow 6)-\beta$-D-glucopyranosyl ester.

Saponin 5 was obtained as a white amorphous powder. The molecular formula of 5 was established as $\mathrm{C}_{59} \mathrm{H}_{96} \mathrm{O}_{26}$ from the quasi-molecular ion at $\mathrm{m} / z 1243.6094\left(\mathrm{calcd}\right.$. for $1243.6088[\mathrm{M}+\mathrm{Na}]^{+}$) in HRESIMS. The 1D NMR spectra data assignable to the aglycone moiety of $\mathbf{5}$ were identical to those of 4 (Table 1), suggesting the same $21 \alpha$-hydroxy-oleanolic acid aglycone. The spectra data assignable to the sugar moieties of 5 were similar to those of $\mathbf{4}$, except for the presence of an additional $\alpha$-L-rhamnopyranose moiety (Rha I). The downfield-shifted carbon signal of Ara C-2 $\left(\delta_{C} 75.5\right)$ in the ${ }^{13} \mathrm{C}-\mathrm{NMR}$ spectrum and the correlation between Rha I H-1 $\left(\delta_{\mathrm{H}} 6.17\right)$ and Ara C-2 $\left(\delta_{\mathrm{C}} 75.5\right)$ observed in the HMBC spectrum indicated that Rha I was attached to Ara C-2. The conclusion was supported by the NOESY spectrum (Figure S4 in Supplementary data). Thus, saponin 5 was 
elucidated as $3 \beta-O-\alpha$-L-rhamnopyranosyl-( $(1 \rightarrow 2)-\alpha$-L-arabinopyranosyl $21 \alpha$-hydroxy-oleanolic acid 28-O- $\alpha$-L-rhamnopyranosyl-(1 $\rightarrow 4)-\beta$-D-glucopyranosyl-( $1 \rightarrow 6)-\beta$-D-glucopyranosyl ester.

Additionally, the eight known saponins were identified as kalopanax saponin A (6) [28], pulsatilloside D (7) [29], 3 $\beta-O-\{\beta$-D-glucopyranosyl- $(1 \rightarrow 2)-\alpha$-L-arabinopyranosyl $\}$ oleanolic acid 28-O- $\beta$-D-glucopyranoside (8) [30], cauloside D (9) [31], cauloside F (10) [32], hederasaponin B (11) $[33], 3 \beta-O-\{\alpha$-L-rhamnopyranosyl-( $1 \rightarrow 2)-[\beta$-D-glucopyranosyl- $(1 \rightarrow 4)]-\alpha$-L-arabinopyranosyl $\}$ betulinic acid $28-O-\alpha$-L-rhamnopyranosyl-( $1 \rightarrow 4)-\beta$-D-glucopyranosyl-( $1 \rightarrow 6)-\beta$-D-glucopyranosyl ester (12) [34], and sieboldianoside A (13) [35]. This was accomplished by comparing their physicochemical and spectroscopic data with reported data [28-35].

For a long time, $A$. rivularis var. flore-minore was used as a folk medicine in Shaanxi Province for the treatment of hepatitis [9]. Inhibition of hepatic stellate cell (HSC) proliferation plays a key role in the pathogenesis of liver fibrosis caused by chronic hepatocellular damage [36]. HSC-T6, an immortalized rat hepatic stellate cell line, has generally been applied as a screening tool to evaluate the potential antifibrotic activity [37].

In this study, the anti-proliferative activity of isolated saponins on HSC-T6 cells was evaluated by 3-(4,5-dimethylthiazol-2-yl)-2,5-diphenyltetrazolium bromide MTT colorimetric assay. Colchicine was used as a positive control. As shown in Table 3, saponins $\mathbf{1 2}$ and $\mathbf{1 3}$ displayed potent anti-proliferative activity with $\mathrm{IC}_{50}$ values of 18.21 and $15.56 \mu \mathrm{M}$, respectively. Saponins 3-5 and 8-11 showed moderate antiproliferative activity with $\mathrm{IC}_{50}$ values ranging from 22.85 to $52.65 \mu \mathrm{M}$. These results revealed that the number of monosaccharides in sugar chains (both at C-3 and C-28) increased the anti-proliferative activity (Figure 3). The gypsogenin aglycone saponins (1 and $\mathbf{2}$ ) and monodesmosidic ones (6 and 7) were inactive, which suggested that the aldehyde functional group at C-23 and the free carboxyl functional group at C-28 had negative effects on anti-proliferative activity (Figure 3). It is worth mentioning that the monodesmosidic saponins (the sugar chain attached at C-3 and a free carboxylic acid at C-28) were cytotoxic against tumor cells in previous studies $[10,14,15,17]$. These opposing effects may be due to their different mechanisms against different types of cells. Nevertheless, the anti-proliferative activity of these saponins was very sensitive to their precise functionalization, especially for the sugar moieties. Further research is needed to approach a significative structure-activity relationship.

Table 3. Anti-proliferation activity of saponins $\mathbf{1 - 1 3}$ on HSC-T6 cells (mean $\pm \mathrm{SD}, n=3$ ).

\begin{tabular}{cccc}
\hline Saponins $^{\mathbf{a}}$ & $\mathbf{I C}_{\mathbf{5 0}}(\boldsymbol{\mu} \mathbf{M})$ & Saponins $^{\mathbf{a}}$ & $\mathbf{I C}_{\mathbf{5 0}}(\boldsymbol{\mu M})$ \\
\hline 3 & $28.62 \pm 0.76$ & 10 & $38.62 \pm 1.58$ \\
4 & $22.85 \pm 2.21$ & 11 & $25.43 \pm 2.86$ \\
5 & $25.74 \pm 1.34$ & 12 & $18.21 \pm 0.92$ \\
8 & $52.65 \pm 3.19$ & 13 & $15.56 \pm 1.58$ \\
9 & $43.65 \pm 2.85$ & Colchicine $^{\mathrm{b}}$ & $9.35 \pm 0.25$ \\
\hline
\end{tabular}

a Compounds 1, 2, 6, and 7 were inactive $\left(\mathrm{IC}_{50}>80 \mu \mathrm{M}\right){ }^{\mathrm{b}}$ Colchicine was used as a positive control.

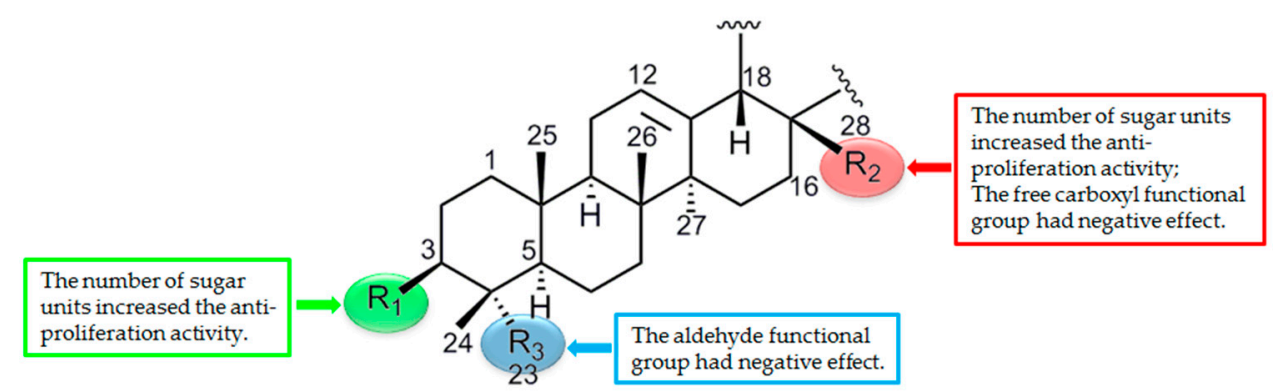

Figure 3. Brief structure-activity relationship analysis of the isolated saponins. 


\section{Experimental Section}

\subsection{General}

Optical rotations were performed on a Perkin-Elmer 343 polarimeter (Perkin-Elmer Inc., Bridgeport, CT, USA). The ESIMS and HRESIMS were carried out on a Micromass Quattro mass spectrometer (Micromass Inc., Manchester, UK). NMR data were recorded on a Bruker AVANCE-500 spectrometer (Bruker Biospin AG, Fallanden, Switzerland). GC was tested on a Finnigan Voyager apparatus with an L-Chirasil-Val column $\left(0.32 \mathrm{~mm} \times 25 \mathrm{~m}\right.$; injector temperature: $230{ }^{\circ} \mathrm{C}$; column temperature: $100-180{ }^{\circ} \mathrm{C}$, rate $5{ }^{\circ} \mathrm{C} / \mathrm{min}$; column head pressure: $12 \mathrm{~Pa}$; carrier gas: $\mathrm{He}, 2 \mathrm{~mL} / \mathrm{min}$ ) (Thermo Finnigan Inc, San Jose, CA, USA). Semi-preparative HPLC was performed on a Dionex P680 liquid chromatograph (Dionex Inc, Sunnyvale, CA, USA) equipped using a UV $170 \mathrm{UV} /$ Vis detector at 206 nm. A YMC-Pack R\&D ODS-A column $(20 \times 250$ mm i.d., 5 m, YMC Co., Ltd., Kyoto, Japan $)$ was used. Materials for column chromatography (CC) were silica gel (10-40 $\mu \mathrm{m}$, Qingdao Marine

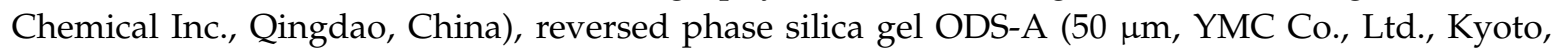
Japan), and Sephadex LH-20 (40-70 $\mu \mathrm{m}$, GE-Healthcare, Uppsala, Sweden). The Liebermann-Burchard reagent was prepared with acetic anhydride and sulfuric acid (Tianjin Fuyu Fine Chemical Co., Ltd., Tianjin, China), and the Molisch reagent was prepared with $\alpha$-naphthol and sulfuric acid (Tianjin Fuyu Fine Chemical Co., Ltd., Tianjin, China).

\subsection{Plant Material}

The plant material was collected on Tsinling Mountains, Shaanxi Province, China, in October 2016. The plant was identified by Prof. Ji-Tao Wang at the Department of Pharmacognosy, School of Pharmacy, Shaanxi University of Chinese Medicine. A voucher specimen (No. 161018) was deposited in the Herbarium of Shaanxi University of Chinese Medicine.

\subsection{Extraction and Isolation}

The air-dried whole plants of $A$. rivularis var. flore-minore $(5 \mathrm{~kg})$ were powdered and extracted with $70 \% \mathrm{EtOH}(3 \times 8 \mathrm{~L} \times 2 \mathrm{~h})$ under reflux to give a crude extract $(800 \mathrm{~g})$, which was further suspended in water $(8 \mathrm{~L})$ and partitioned successively with petroleum ether $(8 \mathrm{~L} \times 2)$ and $n$ - $\mathrm{BuOH}(8 \mathrm{~L} \times 2)$. The $n$-BuOH extract (140 g) was divided into seven fractions (Fr. 1-Fr. 7) by using silica gel CC with a stepwise gradient of $\mathrm{CHCl}_{3}-\mathrm{MeOH}-\mathrm{H}_{2} \mathrm{O}$ (10:1:0.04-6:4:0.7). Fr. 4 (16.5 g) was separated by silica gel CC with a $\mathrm{CHCl}_{3}-\mathrm{MeOH}-\mathrm{H}_{2} \mathrm{O}$ gradient (10:1:0.1-7:3:0.4) to give six sub-fractions (Fr. 4.1-Fr. 4.6) and further purified by on a Sephadex LH-20 column in MeOH. Saponins 6 (37 mg, $\left.t_{\mathrm{R}} 17.4 \mathrm{~min}\right)$ and 7 $\left(26 \mathrm{mg}, t_{\mathrm{R}} 23.5 \mathrm{~min}\right)$ were obtained from Fr. 4.3 (2.2 g) by semi-preparative HPLC (MeOH- $\mathrm{H}_{2} \mathrm{O}(82: 18)$, $7.2 \mathrm{~mL} / \mathrm{min})$. Fr. 4.4 (3.2 g) and Fr. 4.5 (2.5 g) were subjected to semi-preparative HPLC to give saponin 8 (18 mg, MeOH-H $\mathrm{H}_{2} \mathrm{O}(61: 39), 8 \mathrm{~mL} / \mathrm{min}, t_{\mathrm{R}} 19.2 \mathrm{~min}$ from Fr. 4.4), saponin 1 (22 mg, MeOH- $\mathrm{H}_{2} \mathrm{O}$ (60:40), $8.0 \mathrm{~mL} / \mathrm{min}, t_{\mathrm{R}} 20.5 \mathrm{~min}$ from Fr. 4.5) and saponin $9\left(20 \mathrm{mg}, \mathrm{MeOH}-\mathrm{H}_{2} \mathrm{O}(60: 40), 8.0 \mathrm{~mL} / \mathrm{min}\right.$, $t_{\mathrm{R}} 24.5 \mathrm{~min}$ from Fr. 4.5). Fr. 5 (23 g) was separated by silica gel CC with a stepwise gradient of $\mathrm{CHCl}_{3}-\mathrm{MeOH}-\mathrm{H}_{2} \mathrm{O}$ gradient (10:1:0.1-7:3:0.4) to yield eight sub-fractions (Fr. 5.1-Fr. 5.8). Fr. 5.2 $(1.8 \mathrm{~g})$ and Fr. 5.3 (2.4 g) were purified by gel CC over Sephadex LH-20 (MeOH), and further submitted to semi-preparative HPLC to give saponin $2\left(24 \mathrm{mg}, \mathrm{MeOH}-\mathrm{H}_{2} \mathrm{O}(72: 28), 8 \mathrm{~mL} / \mathrm{min}, t_{\mathrm{R}} 19.0 \mathrm{~min}\right)$ and $3\left(18 \mathrm{mg}, \mathrm{MeOH}-\mathrm{H}_{2} \mathrm{O}(76: 24), 8 \mathrm{~mL} / \mathrm{min}, t_{\mathrm{R}} 17.5 \mathrm{~min}\right)$, respectively. Saponins $10\left(25 \mathrm{mg}, t_{\mathrm{R}} 18.6 \mathrm{~min}\right)$ and $4\left(16 \mathrm{mg}, t_{\mathrm{R}} 26.9 \mathrm{~min}\right)$ were obtained from Fr. 5.4 by semi-preparative HPLC $\left(\mathrm{MeOH}-\mathrm{H}_{2} \mathrm{O}(58: 42)\right.$, $7.5 \mathrm{~mL} / \mathrm{min})$. Fr. 5.5 (4.3 g) was subjected to ODS CC with a MeOH- $\mathrm{H}_{2} \mathrm{O}(1: 10-3: 1)$ gradient to afford Fr. 5.5.1-Fr. 5.5.4. Saponins $11\left(35 \mathrm{mg}, t_{\mathrm{R}} 23.5 \mathrm{~min}\right)$ and $5\left(20 \mathrm{mg}, t_{\mathrm{R}} 27.3 \mathrm{~min}\right)$ were obtained from Fr. 5.5 .3 by semi-preparative HPLC ( $\left.\mathrm{MeOH}-\mathrm{H}_{2} \mathrm{O}(58: 42), 8 \mathrm{~mL} / \mathrm{min}\right)$. Fr. 6 (16 g) was separated by silica gel $\mathrm{CC}$ with a stepwise gradient of $\mathrm{CHCl}_{3}-\mathrm{MeOH}-\mathrm{H}_{2} \mathrm{O}(8: 2: 0.2-6: 4: 0.5)$ to yield Fr. 6.1-Fr. 6.5. Fr. 6.2 (4.5 g) was subjected to ODS CC with a stepwise $\mathrm{MeOH}-\mathrm{H}_{2} \mathrm{O}(1: 4-4: 1)$ gradient to afford four Fr. 6.2.1-Fr. 6.2.4. Saponins 12 (18 mg, $\left.\mathrm{MeOH}-\mathrm{H}_{2} \mathrm{O}(70: 30), 8 \mathrm{~mL} / \mathrm{min}, t_{\mathrm{R}} 15.2 \mathrm{~min}\right)$ and 13 (26 mg, 
$\mathrm{MeOH}-\mathrm{H}_{2} \mathrm{O}$ (68:32), $8 \mathrm{~mL} / \mathrm{min}, t_{\mathrm{R}} 18.5 \mathrm{~min}$ ) were obtained by semi-preparative HPLC from Fr. 6.2.2 and Fr. 6.2.3, respectively. The purity of all compounds was assessed by HPLC as more than $95 \%$.

\subsection{Compound Characterization Data}

Compound 1: White amorphous powder; $[\alpha]_{D}^{22}+21.5$ (c 0.18, MeOH); for ${ }^{1} \mathrm{H}-$ and ${ }^{13} \mathrm{C}-\mathrm{NMR}$ spectroscopic data, see Tables 1 and 2; key HMBC and NOESY correlations, see Figure 2; HRESIMS (pos. ion mode) $m / z 933.4829[\mathrm{M}+\mathrm{Na}]^{+}$(calcd. for $\mathrm{C}_{47} \mathrm{H}_{74} \mathrm{NaO}_{17}, 933.4824$ ); ESIMS (pos. ion mode) $m / z 933[\mathrm{M}+\mathrm{Na}]^{+}$.

Compound 2: White amorphous powder; $[\alpha]]_{D}^{22}-11.6$ (c 0.15, MeOH); for ${ }^{1} \mathrm{H}-$ and ${ }^{13} \mathrm{C}-\mathrm{NMR}$ spectroscopic data, see Tables 1 and 2; key HMBC and NOESY correlations, see Figure S1 in Supplementary data; HRESIMS (pos. ion mode) $m / z 1065.5252[\mathrm{M}+\mathrm{Na}]^{+}$(calcd. for $\mathrm{C}_{52} \mathrm{H}_{82} \mathrm{NaO}_{21}$, 1065.5246); ESIMS (pos. ion mode) $m / z 1065[\mathrm{M}+\mathrm{Na}]^{+}$.

Compound 3: White amorphous powder; $[\alpha]_{D}^{22}+17.2$ (c 0.20, MeOH); for ${ }^{1} \mathrm{H}$ - and ${ }^{13} \mathrm{C}-\mathrm{NMR}$ spectroscopic data, see Tables 1 and 2; key HMBC and NOESY correlations, see Figure S2 in Supplementary data; HRESIMS (pos. ion mode) $m / z 1081.8564[\mathrm{M}+\mathrm{Na}]^{+}$(calcd. for $\mathrm{C}_{53} \mathrm{H}_{86} \mathrm{NaO}_{21}$, 1081.8559); ESIMS (pos. ion mode) $m / z 1081[\mathrm{M}+\mathrm{Na}]^{+}$.

Compound 4: White amorphous powder; $[\alpha]_{D}^{22}+12.3($ c $0.14, \mathrm{MeOH})$; for ${ }^{1} \mathrm{H}$ - and ${ }^{13} \mathrm{C}-\mathrm{NMR}$ spectroscopic data, see Tables 1 and 2; key HMBC and NOESY correlations, see Figure S3 in Supplementary data; HRESIMS (pos. ion mode) $m / z 1097.5515[\mathrm{M}+\mathrm{Na}]^{+}$(calcd. for $\mathrm{C}_{53} \mathrm{H}_{86} \mathrm{NaO}_{22}$, 1097.5508); ESIMS (pos. ion mode) $m / z 1097[\mathrm{M}+\mathrm{Na}]^{+}$.

Compound 5: White amorphous powder; $[\alpha]_{D}^{22}-11.4$ (c 0.15, MeOH); for ${ }^{1} \mathrm{H}-$ and ${ }^{13} \mathrm{C}-\mathrm{NMR}$ spectroscopic data, see Tables 1 and 2; key HMBC and NOESY correlations, see Figure S4 in Supplementary data; HRESIMS (pos. ion mode) $m / z 1243.6094[\mathrm{M}+\mathrm{Na}]^{+}$(calcd. for $\mathrm{C}_{59} \mathrm{H}_{96} \mathrm{NaO}_{26}$, 1243.6088); ESIMS (pos. ion mode) $m / z 1243[\mathrm{M}+\mathrm{Na}]^{+}$.

\subsection{Acid Hydrolysis and GC Analysis of the Sugar Moieties in $\mathbf{1 - 5}$}

Saponins 1-5 (each $4 \mathrm{mg}$ ) were hydrolyzed with $2 \mathrm{~mol} / \mathrm{L} \mathrm{CF}_{3} \mathrm{COOH}(5 \mathrm{~mL})$ at $100{ }^{\circ} \mathrm{C}$ for $3 \mathrm{~h}$, respectively. The mixture of reactants was evaporated in vacuo, and the residue was partitioned between $\mathrm{H}_{2} \mathrm{O}$ and $\mathrm{CHCl}_{3}$ three times. The residue was dissolved in pyridine $(4 \mathrm{~mL})$ and 1-(trimethylsilyl)-imidazole $(0.5 \mathrm{~mL})$. The reaction mixture was stirred at $60{ }^{\circ} \mathrm{C}$ for $5 \mathrm{~min}$ and dried with a stream of $\mathrm{N}_{2}$. Then, the residue was partitioned between $\mathrm{H}_{2} \mathrm{O}$ and hexane, and the latter layer was subjected to GC analysis with an L-Chirasil-Val column. The configurations of the monosaccharide units were established by comparing retention times with those of the trimethylsilylated derivatives prepared in the same manner from the authentic standard monosaccharides [38]. Retention times for authentic samples were detected at 8.92 and $9.95 \mathrm{~min}$ (D-arabinose), 9.60 and $10.38 \mathrm{~min}$ (L-rhamnose), 10.91 and $12.15 \mathrm{~min}$ (D-xylose), and $14.82 \mathrm{~min}$ (D-glucose), respectively. L-arabinose, L-rhamnose, and D-glucose were measured in a ratio of 1:1:1 for 1, 1:1:2 for 3 and 4, and 1:2:2 for 5, while the sugar moieties of 2 were identified as L-arabinose, L-rhamnose D-xylose and D-glucose in the ratio of 1:1:1:1.

\subsection{HSC-T6 Cell Culture and Cell Viability Assay}

The anti-proliferative activity of saponins 1-13 was evaluated on hepatic stellate cell (HSC)-T6 cells (Chinese Academy of Science Committee Type Culture Collection Cell Bank, Shanghai, China). The HSC-T6 cells were found to be mycoplasma free by PCR. HSC-T6 cells were maintained in dulbecco's modified Eagle's medium (DMEM) (Sigma-Aldrich, St. Louis, MO, USA), which was supplemented with $10 \%$ heat-inactivated fetal bovine serum, $100 \mathrm{IU} / \mathrm{mL}$ penicillin (Sigma-Aldrich), and $100 \mu \mathrm{g} / \mathrm{mL}$ streptomycin (Sigma-Aldrich) at $37^{\circ} \mathrm{C}$ in a humidified atmosphere of $95 \%$ air-5\% $\mathrm{CO}_{2}$. Cell viability was evaluated by MTT colorimetric assay, with colchicine (Sigma-Aldrich) used as a positive control. The cells were seeded in 96-well plates at a density of $5 \times 10^{4}$ cells $/ \mathrm{mL}$ and incubated for $24 \mathrm{~h}$. Each saponin was dissolved in DMSO and diluted with distilled water to reach the desired concentrations. The cells were treated with these drugs $(0.5,1,5,10,20,40$, and $80 \mu \mathrm{M})$ 
in triplex wells for $48 \mathrm{~h}$ at $37{ }^{\circ} \mathrm{C}$ in a humidified $5 \% \mathrm{CO}_{2}$ atmosphere. An amount of $20 \mu \mathrm{L}$ MTT (Sigma-Aldrich) reagent solved in PBS was added to each well (final concentration $=5 \mathrm{mg} / \mathrm{mL}$ ), and further incubated for $4 \mathrm{~h}$. After removing the supernatant, DMSO was added to solubilize the formazan crystals. The optical density of each well was measured with a Bio-Rad 680 microplate reader at $560 \mathrm{~nm}$. Anti-proliferative activity was expressed as the concentration of compound producing 50\% of cell inhibitory rate $\left(\mathrm{IC}_{50}\right)$.

\section{Conclusions}

In this study, thirteen triterpenoid saponins, including five new ones, were isolated from $A$. rivularis var. flore-minore. All the structures were established on the basis of extensive spectroscopic studies along with MS analyses and acid hydrolysis. Five kinds of aglycones were identified, i.e., gypsogenin, betulinic acid, 21-hydroxy-oleanolic acid, hederagenin, and oleanolic acid. The lupane-type saponins (3 and 12) were reported from the Anemone genus for the first time. The anti-proliferative activity of all isolated saponins was evaluated on hepatic stellate cells (HSC-T6). The preliminary structure-activity relationship analyses revealed that the more monosaccharides the saponins possessed, the stronger the anti-proliferative activity exhibited. This work will not only enrich the diversity of triterpenoid saponins of this genus, but will also provide a reference for the discovery of potential lead compounds for liver disease drug development.

Supplementary Materials: Supplementary data associated with this article can be found online. Table S1. ${ }^{13} \mathrm{C}-\mathrm{NMR}(125 \mathrm{MHz})$ chemical shifts of compounds 6-9 in pyridine- $d_{5}$; Table S2. 13C-NMR (125 MHz) chemical shifts of compounds 10-13 in pyridine- $d_{5}$; Figure S1. Key NOESY and HMBC correlations for compound 2; Figure S2. Key NOESY and HMBC correlations for compound 3; Figure S3. Key NOESY and HMBC correlations for compound 4; Figure S4. Key NOESY and HMBC correlations for compound 5.

Acknowledgments: This work was supported by the National Natural Science Foundation of China (No. 81274029), the Logistics Scientific Research Project of PLA (No. BWS14C050) and the Beijing Science and Technology Planning Project (No. Z171100001717002 and Z131100002513005).

Author Contributions: J.H. and H.-F.T. conceived and designed the experiments; X.-Y.W., X.-J.X. and J.J. contributed to the isolation and structural elucidation; H.G. and M.-Z.-H.Z. realized the evaluation of bioactivities; Y.-P.Z., R.L. and M.N. performed the acid hydrolysis and GC analysis; X.-Y.W. wrote the paper.

Conflicts of Interest: The authors declare no conflict of interest.

\section{References}

1. Sun, Y.X.; Liu, J.C.; Liu, D.Y. Phytochemicals and bioactivities of Anemone raddeana Regel: A review. Pharmazie 2011, 66, 813-821. [PubMed]

2. Wang, J.L.; Liu, K.; Gong, W.Z.; Wang, Q.; Xu, D.T.; Liu, M.F.; Bi, K.L.; Song, Y.F. Anticancer, antioxidant, and antimicrobial activities of Anemone (Anemone cathayensis). Food Sci. Biotechenol. 2012, 21, 551-557. [CrossRef]

3. Zhang, L.T.; Zhang, Y.W.; Takaishi, Y.; Duan, H.Q. Antitumor triterpene saponins from Anemone flaccida. Chin. Chem. Lett. 2008, 19, 190-192. [CrossRef]

4. Wang, J.R.; Ma, J.Q.; Peng, L.L.; Feng, J.T.; Ding, L.S. Chemical constituents and antifeeding activity of Anemone tomentosa. Acta Bot. Boreali-Occid. Sin. 1998, 18, 643-644.

5. Ye, W.C.; Zhang, Q.W.; Zhao, S.X.; Che, C.T. Four new oleanane saponins from Anemone anhuiensis. Chem. Pharm. Bull. 2001, 49, 632-634. [CrossRef] [PubMed]

6. Lu, J.C.; Xu, B.B.; Gao, S.; Fan, L.; Zhang, H.F.; Liu, R.X.; Kodama, H. Structure elucidation of two triterpenoid saponins from rhizome of Anemone raddeana Regel. Fitoterapia 2009, 80, 345-348. [CrossRef] [PubMed]

7. Wang, M.K.; Wu, F.E.; Chen, Y.Z. Triterpenoid saponins from Anemone hupehensis. Phytochemistry 1997, 44, 333-335. [CrossRef]

8. Mimaki, Y.; Watanabe, K.; Matsuo, Y.; Sakagami, H. Triterpene glycosides from the tubers of Anemone coronaria. Chem. Pharm. Bull. 2009, 57, 724-729. [CrossRef] [PubMed]

9. Flora of China Editorial Committee of Chinese Academy of Sciences. Flora of China; Science Press: Beijing, China, 1980; Volume 28, p. 24. 
10. Wang, X.Y.; Chen, X.L.; Tang, H.F.; Gao, H.; Tian, X.R.; Zhang, P.H. Cytotoxic triterpenoid saponins from the rhizomes of Anemone taipaiensis. Planta Med. 2011, 77, 1550-1554. [CrossRef] [PubMed]

11. Ding, Y.; Tang, H.F.; Wang, J.B.; Liu, D.; Tian, X.R.; Wang, X.Y.; Zhou, X.M. Triterpenoid saponins from Anemone rivularis var. flore-minore. Biochem. Syst. Ecol. 2011, 39, 236-239. [CrossRef]

12. Ding, Y.; Tian, X.R.; Tang, H.F.; Feng, J.T.; Zhang, W.; Hai, W.L.; Wang, X.Y.; Wang, Y. Two new glycosides from the whole plant of Anemone rivularis var. flore-minore. Phytochem. Lett. 2012, 5, 668-672. [CrossRef]

13. Wang, Y.; Kang, W.; Hong, L.J.; Hai, W.L.; Wang, X.Y.; Tang, H.F.; Tian, X.R. Triterpenoid saponins from the root of Anemone tomentosa. J. Nat. Med. 2013, 67, 70-77. [CrossRef] [PubMed]

14. Wang, X.Y.; Zhang, W.; Gao, K.; Lu, Y.Y.; Tang, H.F.; Sun, X.L. Oleanane-type saponins from the rhizomes of Anemone taipaiensis and their cytotoxic activities. Fitoterapia 2013, 89, 224-230. [CrossRef] [PubMed]

15. Wang, X.Y.; Gao, H.; Zhang, W.; Li, Y.; Cheng, G.; Sun, X.L.; Tang, H.F. Bioactive oleanane-type saponins from the rhizomes of Anemone taipaiensis. Bioorg. Med. Chem. Lett. 2013, 23, 5714-5720. [CrossRef] [PubMed]

16. Li, H.; Wang, XY.; Wang, X.Y.; Hua, D.; Liu, Y.; Tang, H.F. Two new triterpenoid saponins from the aerial parts of Anemone taipaiensis. J. Asian. Nat. Prod. Res. 2015, 17, 576-582. [CrossRef] [PubMed]

17. Wang, X.Y.; Wang, M.C.; Xu, M.; Wang, Y.; Tang, H.F.; Sun, X.L. Cytotoxic oleanane-type triterpenoid saponins from the rhizomes of Anemone rivularis var. flore-minore. Molecules 2014, 19, 2121-2134. [CrossRef] [PubMed]

18. Nie, R.L.; Tanakaa, T.; Miyakoshia, M.; Kasaia, R.; Moritaa, T.; Zhou, J.; Tanaka, O. A triterpenoid saponin from Thladiantha hookeri var. pentadactyla. Phytochemistry 1989, 28, 1711-1715. [CrossRef]

19. Mahato, S.B.; Kundu, A.P. ${ }^{13}$ C NMR Spectra of pentacyclic triterpenoids-A compilation and some salient features. Phytochemistry 1994, 37, 1517-1575. [CrossRef]

20. De Marino, S.; Borbone, N.; Iorizzi, M.; Esposito, G.; McClintock, J.B.; Zollo, F. Bioactive asterosaponins from the starfish Luidia quinaria and Psilaster cassiope. Isolation and structure characterization by two-dimensional NMR spectroscopy. J. Nat. Prod. 2003, 66, 515-519. [CrossRef] [PubMed]

21. Zheng, Q.; Koike, K.; Han, L.K.; Okuda, H.; Nikaido, T. New biologically active triterpenoid saponins from Scabiosatschiliensis. J. Nat. Prod. 2004, 67, 604-613. [CrossRef] [PubMed]

22. Xu, T.H.; Xu, Y.J.; Li, H.X.; Han, D.; Zhao, H.F.; Xie, S.X.; Xu, D.M. Two new triterpenoid saponins from Pulsatillacernua (Thunb.) Bercht. etOpiz. J. Asian Nat. Prod. Res. 2007, 9, 705-711. [CrossRef] [PubMed]

23. Mimaki, Y.; Yokosuka, A.; Kuroda, M.; Hamanaka, M.; Sakuma, C.; Sashida, Y. New bisdesmosidic triterpene saponins from the roots of Pulsatilla chinensis. J. Nat. Prod. 2001, 64, 1226-1229. [CrossRef] [PubMed]

24. Zhang, X.; Zou, L.H.; He, Y.L.; Peng, C.; Guo, L.; Xiong, L. Triterpenoid saponins from the buds of Lonicera similis. Nat. Prod. Res. 2017, 30,1-9. [CrossRef] [PubMed]

25. Werner, S.; Nebojsa, S.; Robert, W.; Robert, S.; Olaf, K. Complete assignments of ${ }^{1} \mathrm{H}$ and ${ }^{13} \mathrm{C}$ NMR resonances of oleanolic acid, $18 \alpha$-oleanolic acid, ursolic acid and their 11-oxo derivatives. Magn. Reson. Chem. 2003, 41, 636-638.

26. Zhang, W.; Yao, M.N.; Tang, H.F.; Tian, X.R.; Wang, M.C.; Ji, L.J.; Xi, M.M. Triterpenoid saponins with anti-myocardial ischemia activity from the whole plants of Clematis tangutica. Planta Med. 2013, 79, 673-679. [CrossRef] [PubMed]

27. Mimaki, Y.; Yokosuka, A.; Hamanaka, M.; Sakuma, C.; Yamori, T.; Sashida, Y. Triterpene saponins from the roots of Clematis chinensis. J. Nat. Prod. 2004, 67, 1511-1516. [CrossRef] [PubMed]

28. Zhao, M.; Da-Wa, Z.M.; Guo, D.L.; Fang, D.M.; Chen, X.Z.; Xu, H.X.; Gu, Y.C.; Xia, B.; Chen, L.; Ding, L.S.; et al. Cytotoxic triterpenoid saponins from Clematis tangutica. Phytochemistry 2016, 130, 228-237. [CrossRef] [PubMed]

29. Ye, W.C.; Pan, G.S.; Zhang, Q.W.; Che, C.T.; Wu, H.M.; Zhao, S.X. Five new triterpene saponins from Pulsatilla patens var. multifida. J. Nat. Prod. 1999, 62, 233-237. [CrossRef] [PubMed]

30. Khalik, S.M.; Miyase, T.; El-Ashaal, H.A.; Melek, F.R. Triterpenoid saponins from Fagonia cretica. Phytochemistry 2000, 54, 853-859. [CrossRef]

31. Maeda, C.; Ohtani, K.; Kasai, R.; Yamasaki, K.; Nguyen, M.D.; Nguyen, T.N.; Nguyen, K.Q. Oleanane and ursane glycosides from Schefflera octophylla. Phytochemistry 1994, 37, 1131-1137. [CrossRef]

32. Elias, R.; Lanza, A.M.D.; Vidalollivier, E.; Balansard, G.; Faure, R. Triterpenoid Saponins from the Leaves of Hedera helix. J. Nat. Prod. 1991, 54, 98-103. [CrossRef]

33. Chen, X.; Lu, J.; He, W.; Chi, H.; Yamashita, K.; Manabe, M.; Kodama, H. Antiperoxidation activity of triterpenoids from rhizome of Anemone raddeana. Fitoterapia 2009, 80, 105-111. [CrossRef] [PubMed] 
34. Yang, H.; Cho, Y.W.; Kim, S.H.; Kim, Y.C.; Sung, S.H. Triterpenoidal saponins of Pulsatilla koreana roots. Phytochemistry 2010, 71, 1892-1899. [CrossRef] [PubMed]

35. Jiang, D.; Shi, S.P.; Gao, J.J.; Gao, Q.P.; Tu, P.F. Triterpene saponins from the fruits of Akebia quinata. Biochem. Syst. Ecol. 2008, 36, 138-141. [CrossRef]

36. Friedman, S.L. Hepatic stellate cells: protean, multifunctional, and enigmatic cells of the liver. Physiol. Rev. 2008, 88, 125-172. [CrossRef] [PubMed]

37. Li, D.; Friedman, S.L. Liver fibrogenesis and the role of hepatic stellate cells: New insights and prospects for therapy. J. Gastroenterol. Hepatol. 1999, 14, 618-633. [CrossRef] [PubMed]

38. Masullo, M.; Calabria, L.; Gallotta, D.; Pizza, C.; Piacente, S. Saponins with highly hydroxylated oleanane-type aglycones from Silphium asteriscus L. Phytochemistry 2014, 97, 70-80. [CrossRef] [PubMed]

Sample Availability: Samples of the compounds 1-13 are available from the authors.

(C) 2018 by the authors. Licensee MDPI, Basel, Switzerland. This article is an open access article distributed under the terms and conditions of the Creative Commons Attribution (CC BY) license (http:/ / creativecommons.org/licenses/by/4.0/). 